\title{
THEOLOGY, IMAGINATION AND POPULAR MUSIC
}

\author{
GAVIN HoPpS
}

God loveth adverbs; and cares not how good, but how well.

(Joseph Hall)

In what ways might popular music be related to the religious? If we leave aside the Barth-

like rebuttal 'Keineswegs!', most answers to this question appear to fall into one of three broad categories: (i) it can be made by religious artists; (ii) it can deal with religious subjects; and (iii) it can aspire to elicit religious experience. ${ }^{1}$ Thus, with reference to the first category, an artist such as Sufjan Stevens, for example, who identifies himself as a Christian but who often writes songs without any overt religious references, may nonetheless be thought of as making 'religious' music. Stevens has said something similar himself:

It's not so much that faith influences us as it lives in us. In every circumstance (giving a speech or tying my shoes), I am living and moving and being. This absolves me from ever making the embarrassing effort to gratify God (and the church) by imposing religious content on anything I do. I mean, I've written songs about stalkers. Is that any less religious than a song about an ordained pastor? No way. (Stevens 2006)

If this is the case, it seems that popular music might still in some way be considered religious — to the artist and perhaps for the audience too—even when it lacks 'religious content'. ${ }^{2}$ This makes more sense if, as musicologists such as Christopher Small recommend, we cease to conceptualize music 'nominally' as a self-contained autonomous object and think about it 'verbally' as an activity, for which he coins the term 'musicking':

\footnotetext{
${ }^{1}$ Another way of putting this is to say the locus of significance is primarily situated 'behind', 'within' or 'in front of the work. These three categories correspond to the major theoretical approaches to the study of music and emotion, which centre on expression, resemblance and arousal or affect.

${ }^{2}$ For an illuminating discussion of various ways in which artworks might be related to or enjoyed 'in God', see Burch Brown (2000: 117ff.). Several of Burch Brown's categories—such as dedicating or consecrating something to God-highlight the role of the subject's disposition in determining a religious dimension. See also Wolterstorff (1980) for a sustained defence of 'intentionality' as a criterion of aesthetic and religious significance.
} 
The act of musicking establishes in the place where it is happening a set of relationships, and it is in those relationships that the meaning of the act lies. They are to be found not only between those organized sounds which are conventionally thought of as being the stuff of musical meaning but also between the people who are taking part, in whatever capacity, in the performance; [...] relationships between person and person, between individual and society, between humanity and the natural world and even perhaps the supernatural world. (1998: 13)

Music, in other words, is a dynamic event, whose meaning doesn't reside 'immanently' within the work but is instead more widely distributed across a relational field of subjects and objects in a state of performatively constituted entanglement-which, according to Small, may even extend beyond the terrestrial sphere to include the supernatural. In terms of this dynamic model of 'musicking', then, we might think of religious significance as an 'adverbial' as well as a 'substantive' matter-which is to say, a 'how' as well as a 'what'-since, in addition to the possibility that a piece of music may, on account of its subject matter, be seen as religious in itself, it is also possible to make or listen to music 'religiously', irrespective of its content. Whilst this might at first seem somewhat odd, it is in principle no different from the commonly accepted idea that one can appreciate or perform a piece of religious music, outside its original liturgical context, purely 'as music', without any sort of religious involvement (playing Bach's MatthäusPassion in a concert hall or doing aerobics to Gregorian chant). In short, what I am suggesting is that, just as one can engage with religious music 'secularly', it may be possible conversely to perform or listen to secular music 'religiously'.

The second of our three definitional categories is much more straightforward, and corresponds to most people's default sense of what is meant when we talk about religious music. Yet, as we shall see, these 'substantive' engagements with religious subjects encompass a wide variety of moods or modes—such as the interrogative, the

\footnotetext{
${ }^{3}$ This way of thinking has precedents in the socio-political sphere (the political philosopher Michael Oakeshott proposed that we should think about human conduct in terms of 'adverbial' conditions rather than 'substantive' practices); though it also has a theological precedent in the work of Augustine, whose famous distinction between 'frui' and 'uti' evinces a sort of 'adverbial' logic and who argues more pervasively in The City of God that the realm to which we ultimately belong is determined not according to what we love but according to the kind of love we exhibit.
} 
subjunctive and the optative, in addition to the indicative. So, for instance, Morrissey's song 'I Have Forgiven Jesus' puts us in the midst of religious concerns, in a way that may be productive for theological inquiry, even as it interrogates and evinces an animosity towards the divine. (One of the general things I wish to do in this essay is to suggest that theological significance isn't simply a matter of correspondence with Scripture or its distillation into doctrinal postulates; instead, I want to widen the focus to take cognizance of what music can $d o$ and to consider the possibility that a divergence from or contestation of theological teaching may also paradoxically be of value from a religious perspective.)

The third category is the widest or at least the most open, since religious significance in this case has little, if anything, to do with the author's 'intentions' and is not simply determined by the text 'in itself. Rather, it is an 'adverbial' matter that has more to do with music's affect upon the listener, which manifestly cannot be established in advance. Approaches that focus on this third category-and see the meaning of a musical event as co-constituted by the act of reception-may be helpfully explained in terms of Small's 'rhizomatic' model of musicking, which reconceptualizes music as an acentred activity whose meaning is distributed across an ensemble of relations that includes the listener. ${ }^{4}$ However, they also correlate with a number of contemporary theological approaches to the arts, such as David Brown's model of 'sacramentality', Richard Viladesau's conception of music as 'a way to God' and Frank Burch Brown's reevaluation of the spiritual significance of kitsch. ${ }^{5}$ (One might also add to this list of

\footnotetext{
${ }^{4}$ Building on psychological models of 'extended cognition' - in which the human organism is linked with something in its external environment in a way that constitutes a sort of coupled system-Joel Krueger has developed a related theory of the 'musically extended mind', which views music as part of a 'brain-bodymusic' assemblage or a relationally constituted extended system, by means of which certain experiences are realized (Krueger 2013). For a parallel discussion of music as a 'prosthetic' augmentation of the listener's body, which enhances, configures and extends its capacities, see DeNora (2000).

${ }^{5}$ See Brown (2007), Viladesau (2000) and Burch Brown (2000).
} 
'affective' approaches Jean-Luc Marion's work on the idol and the icon, ${ }^{6}$ and Paul Ricoeur's 'performative' account of poetic revelation. ${ }^{7}$ ) Indeed, whilst there are still some theological critics, such as Jeremy Begbie, who doggedly stick to 'essentialist' approaches—contending that certain musical forms are somehow 'in themselves' more Christian than others-there has been a conspicuous shift in the field of theology and the arts in recent years away from exclusively 'immanent' approaches towards more 'affective' models of significance. ${ }^{8}$ This is doubtless in part a response to the more widespread 'turn to affect' across the humanities, but it is also partly a reaction against the prescriptive tendencies of 'catechetical' approaches such as Begbie's, which as Heidi Epstein rather tartly observes, 'reduces music to a mere proof-text for biblical doctrine' (2004: 84). The correlative problem with such approaches, though, is the opportunity cost they entail, since they have a tendency to neglect music's transformative and revelatory capacities — that is, its ability epiphanically to expand our vision, to engender a sense of being opened, to awaken us to the mystery in which we ordinarily unwittingly stand, and perhaps even to mediate experiences of divine presence. ${ }^{9}$

In the present chapter, I shall focus on the two latter categories-that is, popular music's treatment of religious subjects and its ability to elicit religious experienceattending in particular to the role of the imagination-though in the first case the

\footnotetext{
${ }^{6}$ Marion's theory distinguishes between created phenomena not in terms of their substantive properties but in terms of their function or the comportment they engender. Thus, any phenomenon can function as an idol-irrespective of its content-if the gaze it elicits terminates in and is exhausted by its object, just as any phenomenon can function as an icon-again, irrespective of its content—if it orients the gaze beyond itself towards the unenvisageable divine. See Marion (1991).

${ }^{7}$ According to Ricoeur's 'revelatory' construal of poetic discourse, the locus of significance doesn't lie 'behind' or 'within' the text-which is to say, it isn't primarily a matter of authorial intention or preexisting correspondence. Instead, it has a 'cataphoric' referentiality, in that it opens up a world 'in front of the text, which it summons the reader to bring into being. See, for example, Ricoeur (2008).

${ }^{8}$ For a good discussion of the neglect of affective revelatory experiences of God's presence outside the church and the need for a countervailing openness to aesthetic experiences of 'general revelation', see Johnston (2014).

${ }^{9}$ William Dyrness has put forward a sharp critique of Begbie's approach, which highlights the neglect of such concerns: according to Begbie's account 'music is still only metaphor; it is a giver of insight. But perhaps $[\ldots]$ it be can be something more. Can it perhaps be a kind of icon, transparent to its eternal ground? Can it perhaps stop us in our tracks and make us aware of a Presence before which we may be transformed?' (2011: 151).
} 
emphasis will be on 'transitivity' whereas in the second it will be on transformation. In highlighting these two, often interrelated ways in which popular music may be constructively related to the religious, I am implicitly arguing against several critics whose negative readings of popular music have sought to foreclose such possibilities. In particular, I wish to contest Adorno's well-known polemical contention that popular music neither evinces nor elicits imaginative engagement, and Roger Scruton's more recent but similarly tendentious claim that popular music is incapable of engendering contemplative affects. ${ }^{10}$ In the process, however, I also want to extend the compass of attention beyond the 'essentialist' catechetical approach espoused by Jeremy Begbie to take in the function and affects of music. ${ }^{11}$

\section{WHAT HAS GRACELAND TO DO WITH JERUSALEM?}

One of the features of the so-called 're-enchantment' of the West is an increased visibility of the religious as a subject in contemporary popular music (as seen, for example, in the work of artists such as Arcade Fire, Belle and Sebastian, Lupe Fiasco, The Killers, Lady Gaga, Roots Manuva, Mumford and Sons, Prince, Regina Spektor and Kanye West). ${ }^{12}$ Whilst concurring with this thesis in general, I want to complicate it in a couple of divergent ways: on the one hand by calling attention to the variety of

\footnotetext{
${ }^{10}$ A detailed discussion of Adorno and Scruton's views-which there isn't space to consider here-is offered in Hopps (forthcoming).

${ }^{11}$ Whilst Begbie pointedly avoids discussion of popular music — and gives the impression he considers it to be an inferior artform that is of little or no religious significance-his pioneering work on theology and music has nonetheless had an influence on the field. Broadly speaking, the alternative I am proposing may be summarized as follows. Whereas Begbie's approach is 'anaphoric', in that his evaluation of music's significance looks backwards to a template of predetermined correspondences (equating particular musical structures with certain Christological postulates), I wish to advocate a more 'cataphoric' approach-that doesn't ignore but isn't exclusively focused on 'intrinsic' significance-which is oriented more towards the world 'in front of the text, in recognizing the openness of music's affects and in allowing its significance to be determined in part by its functions and uses.

${ }^{12}$ In 2005, The Guardian ran a feature about 'A new breed of rock star: quietly Christian' (Gibson and Barkham 2005), and in 2015 there were articles in The Believer and Consequence of Sound on the prevalence of 'the spiritual in indie' (Berman 2015) and the 'new wave of Christian indie rock', which was opening up 'nuanced discussions of faith inside a largely secular genre' (Sackllah 2015). For an excellent account of contemporary 're-enchantment', which includes a discussion of popular music, see Partridge (2004).
} 
theological moods in which religious concerns may be articulated, and on the other by considering how even secular popular music might be put to religious use. With reference to our foregoing categories, we could say that in the first case the religious significance of such music is 'substantively' constituted, by virtue of its content, whereas in the second case such music may be 'adverbially' related to the religious, by dint of its affects or the experiences it affords—-though obviously the former may also engender religious experience. Perhaps somewhat perversely, the sort of music with which I shall be least concerned in this chapter is straightforwardly affirmative religious music. This is not because I see no aesthetic or theological value in such music, but rather because I wish to widen the demesne of religious significance in suggesting that this is not the only sort of popular music that might be of value from a religious perspective.

\section{I \\ Post-Secular Popular Music}

If the 're-enchantment' of contemporary culture involves a widening or more visible diffusion of religious concerns, most commentators on the subject agree that it also appears to involve some sort of weakening. ${ }^{13} \mathrm{~A}$ helpful way of thinking about this simultaneous widening and weakening of religion in the public sphere is in relation to the theoretical framework of post-secularism.

Very briefly, the label 'post-secular'—which was popularized by Jürgen Habermas, but which had already been in circulation for some time-refers to a stance that ambivalently eschews purely secular constructions of reality without endorsing, in any committed or exclusive sense, a religious alternative. ${ }^{14}$ It therefore, typically, announces a fluid and porous 'in-between' zone, which repudiates all forms of

\footnotetext{
${ }^{13}$ Charles Taylor has described this weakened diffusion of religious faith as a 'nova effect' — which vividly captures the explosive profusion of possible positions-whose defining characteristics are fragmentation, pluralization and fragilization. See Taylor (2007).

${ }^{14}$ In my account of the 'post-secular', I am indebted to McClure (2007).
} 
fundamentalism—whether secular or religious—but which entertains, in a partial or 'weakened' sense, the possibilities of both perspectives. (A common feature of the postsecular outlook is thus a sort of self-deprecating epistemology—as propounded, for example, in Gianni Vattimo's theory of 'weak thought'-which recognizes the contingency, the provisionality and always already interpreted character of any conception of the real.) Although this resembles, and indeed encompasses, traditional 'neither/nor' forms of agnosticism, the post-secular outlook tends to involve a greater openness to mystery and has a more hybridized or 'overdetermined' character, which includes a variety of conflicted, questioning, ironic, subjunctive, 'excessive' and paradoxical postures. Whilst it obviously isn't possible to provide anything like a complete account, what I wish to try and do in the space available is to sketch out some of the most prominent forms that such a post-secular outlook might take in popular music. As a heuristic convenience, I shall identify a number of discrete categories, though manifestly things are not so neat and tidy in practice, and many songs will fall into more than one of these categories.

\section{The In-Between}

One of the clearest illustrations of a post-secular outlook is the restless and roving agnosticism of those who find themselves in a 'no-man's land' between religious and secular commitments. This might take the form of a hesitant or interrogative engagement with the religious, as we find in a song like 'The Eye Of The Needle' by the British pop band The Divine Comedy, in which the song's narrator attends a religious service and watches the worshippers taking communion, with a combination of yearning and aversion—at once drawn towards and yet unable to adopt a religious stance. The song doesn't simply describe a past and private event, however; rather, by dramatizing the experience in the 'timeless' present of the narrative, the song entices the listener to 
imagine their way into the speaker's predicament. This is most obvious towards the end of the song, where the final utterance ('All through communion, I stare at the people, / Squeezing their way through the eye of the needle') is followed by an extended outro pastiche of the most exquisitely mournful communion music, with a foregrounded 'ecclesial' organ harmony, which presents the events the song describes as going on in front of us, and thus draws the listener into the experiencing perspective of the speaker. In this way, the song invites the agnostic listener to enter into a stance of wondering, which manifestly keeps its distance from commitment but is open to the possibility of faith. $^{15}$

\section{Oxymoronic Postures}

Another common manifestation of the post-secular outlook involves what John McClure refers to as the 'double practice of disavowal and reaffirmation' (2007: 13), as seen for instance in Antony and the Johnsons' 'Rapture'—from their 1998 debut album—which slowly unfolds a litany of deterioration, playing on various senses of 'falling': 'Eyes are falling, lips are falling [...] Teardrops falling to the ground [...] Oh my mama, she's been falling [...] Oh my friends, I've watched them falling'. (This vision of all things inexorably falling is rendered all the more harrowing by the plangent vibrato of Hegarty's voice, which quivers with a sort of electric intensity and conveys a sense of radical vulnerability.) The song then delivers its audacious punchline, as the singer sardonically asks of this tragic entropic predicament, 'Is this the rapture?' But the song has an even bigger surprise up its sleeve; for, in a manner reminiscent of the turn to praise in the psalms of lament, there follows a wholly unheralded peripeteia, as the song shifts into

\footnotetext{
15 One can also liberate this sort of in-between space from the opposite direction, in moving away from rather than towards the religious, as in the 'Christ-haunted' work of the American indie singer-songwriter David Bazan-whose solo recordings, after a loss of faith, continue anxiously to wrangle with religious questions - or perhaps even the music of Metallica, whose lyrics have been characterized as a 'theological atheism'. For a discussion of the latter, see Mertens (2005).
} 
orthodox prayer: 'Our father who art in heaven / For the kingdom, the power, the glory, yours now and forever'. It's hard to know quite what to make of this shift. One way of reading it, though, is to see the conclusion as modelling-and inviting the listener to adopt—an 'eschatological' posture, which doesn't seek to deny or escape this-worldly 'falling', but which reminds us that it is possible to look upon it from an alternative transcendent perspective, and thus inhabit this realm of ineluctable degeneration hopefully, even if the source of this hope isn't rooted in any present reality.

This oscillation between disavowal and reaffirmation can of course be multiplied, as it is in Kendrick Lamar's 'Faith', from his eponymous 2009 EP. More precisely, the song, which is musically based around a sample from 'Tired Of Fighting' by Menahan Street Band, begins with a first-person consonant vignette that establishes the singer's transgressive credentials: 'I take a sip of Hennessy and then get pissy drunk / I ain't a drinker, I'm a thinker, call it what you want / But if you turn your back, know that you just missed your chance / To witness the realest shit that's ever been told to man'. Now whilst this may appear to have little to do with the ensuing narratives, its braggadocio, swearing and advertised excess is in fact key to the song's religious functionparadoxically because and not in spite of the fact that its 'indecency' may offend a number of mainline Christians. This is because Lamar appears to be speaking to the unconverted or undecided - to the marginalized and disenfranchised outside the church, not to the hygienically respectable Christian_audiences, in other words, who may be alienated by the voice of sanitized piety. In situating its speaker within a 'profane' milieu, the song may therefore be better able to reach and appeal to its target audience, who might be more inclined to attend to such a figure than someone who speaks de haut en bas from the perspective of ecclesial authority. What follows this vignette is a series of concretely realized parallel narratives about various people finding, losing and struggling to hold onto or make sense of religious faith. But what makes the song especially 
effective from a religious point of view is the way these narratives of wavering faith are interlaced with a beseeching lyrical endorsement of belief—sung by BJ The Chicago Kid in the song's chorus - which seems to proceed from a different diegetic space ('Gotta have faith [...] don't you give up, don't you give in / Faith, all you need is the size of a mustard seed'). By means of this dual vocal perspective, the song is able to acknowledge and yet at the same time offer a counterpoise to-without in any sense softening - the suffering to which its narrative points; and in this way, the song as a whole models a more realistic 'I know very well, but nonetheless' posture of faith in the face of suffering.

\section{Metaphysical Shuddering}

So far, we have been concerned with forms of post-secularism that involve an explicit engagement-however ambivalently — with the religious. But it is also possible to open up or shade over into a post-secular space without directly referring to religious subjects. How is this so? Leaving aside musical evocations of transcendence for now-though obviously these contribute to such effects - it seems to me that we find in the songs of a band like Fleet Foxes an enigmatic radiant vision of nature, which rarely involves explicitly religious references, but which uncannily evokes a 'something more' - a glow, a shadow, a sense of enchantment-that carries them away from a purely materialist conception of the real. ${ }^{16}$ It is therefore no surprise to find references to Yeats' 'Lake Isle of Innisfree'—where 'midnight's all a glimmer' —in a couple of their songs. ${ }^{17}$ This sort of 'haunted immanence' is even more prominent in the less well known work of Mount Eerie-the musical project of American songwriter Phil Elverum—who specializes in songs that dramatize mysteriously liminal intimations of epiphanic experiences in nature, whose uncanny vision is poised somewhere between Wordsworth's Prelude and David

\footnotetext{
${ }^{16}$ The band have themselves referred to music as a 'strange religion for non-believers' (liner notes to Fleet Foxes).

${ }^{17}$ See 'The Shrine/An Argument' and 'Bedouin Dress' on Helplessness Blues (2011).
} 
Lynch's Twin Peaks. ${ }^{18}$ One might also include in this category songs that stage a narcotic epiphany, such as 'Fargo' by the Californian 'drone-folk' band Gowns, which itemizes in a gorgeously harmonized litany all of the drugs the speaker took when she 'stayed up for days in the summer', and then suddenly slows down into a dream-like vision-glowingly intoned over the tremulous stasis of a sustained organ chord - in which the everyday world is epiphanically transfigured: "And the light shining through the window was golden / And the days stretched out as far as the horizon / And you could see the dust float like sparkles in the air'. Once again, although we have been carried beyond a quotidian vision, we haven't crossed over into a religious terrain. And it is in this narcotically conjured in-between space of enchantment that the song leaves the listener.

\section{Ludic Avowal}

Another popular post-secular strategy for weakening the status of one's positings is what McClure refers to as 'ludic avowal' (2007: 16), by which he means the use of absurd excess, extravagant (im)piety and parody in the presentation of religious views. McClure's discussion focuses on the novels of Pynchon, DeLillo and Erdrich, but we find this strategy in popular music too, as wonderfully illustrated in the song 'Ain't Going To Goa' by the Brixton band Alabama 3 (also known as The First Presleyterian Church of Elvis the Divine). What is so consummately accomplished in this song-which musically blends country, blues and acid house, but which also incorporates a miniature rapped sermon by the Very Reverend Dr D. Wayne Love-is the staging of a mode of religious affirmation that shimmers indecipherably between seriousness and irony. Of course, in one sense this weakening appears to signal a suspension of commitment—and the song may, indeed, be nothing more than a very amusing and well-pointed parody. Yet such

${ }^{18}$ See, for example, 'The Place I Live' from Clear Moon (2012), 'Lost Wisdom Pt. 2' or 'Between Two Mysteries' from Wind's Poem (2009), which contains musical allusions to 'Laura Palmer's Theme'. 
weakening can serve a more positive theological function as well, since as McClure observes, it may make the reintroduction of the religious palatable to secular-minded audiences (2007: 16). In this sense, irony may paradoxically make possible, even as it vitiates, the avowal of religious allegiance. This is not to imply that that belief today must always be conjoined with or leavened by irony; although, for some-and perhaps even for certain generations of believers, as Tom Beaudoin has argued—-the posture of faith is inevitably accompanied, if not enabled, by a self-distancing strategy of irony, which advertises an insynchronicity between the speaker and their avowed stance. For Beaudoin, this means that 'faithfulness happens with (or as) a question mark' (1998: 42); however, it seems to me that the self-differing wink of irony can pertain to various aspects of the avowal and isn't necessarily the insignia of scepticism. Instead, it might, for example, signal a dissociation from institutionalized practices or an acknowledgment of belief as a wagering that isn't opposed to but nonetheless reaches beyond the jurisdiction of reason. In other words, I am suggesting that whilst irony may indeed be a cadential question mark that casts doubt upon its own postulations, it might also be seen as a sort of 'apophatic' caveat, whose 'unsaying' is tonally rather than semantically constituted.

\section{Subjunctive Explorations}

Of course, tone isn't the only way of weakening the status of one's positings; this may be done by grammatical mood as well, in removing what's predicated from the indicative sphere and staging it in a subjunctive realm. One of the most popular examples of this is Joan Osborne's 1995 single 'One Of Us', which lures the listener into engaging with religious issues—without commitment, from the safety of a hypothetical distance — with its 'What if postulates. A cheekier and more sceptical variant of this strategy is adopted in Lily Allen's 'Him', which asks if there is some kind of God, do you think He's pleased?' and goes on to wonder - and in doing so prompts the listener to wonder-in 
jokey but also serious terms, about the actions and attributes of God. We also find much less stable and more dramatic hypothetical positings in popular music, in which we sense a reaching through subjunctive space towards some sort of indicative stance, which the speaker cannot fully or finally maintain. Nick Cave's 'Into My Arms', for example, from the 1997 album The Boatman's Call, is a fine illustration of this kind of distended subjunctive. More particularly, the song begins with an apparently emphatic declaration of non-belief: 'I don't believe in an interventionist God'. But this is almost immediately countered by a conditional clause that doesn't gainsay this initial stance, though it opens up a subjunctive space that suspends the speaker's avowal of disbelief and allows him to engage with a God in Whom he claims not to believe: 'But if I did I would kneel down and ask Him / Not to intervene when it came to you'. What's more, this sustained subjunctive engagement leads into a chorus of direct address- 'Into my arms, O Lord'whose wistful vocatives seem to have shed all trace of their subjunctive lineaments and shaded over into an act of prayer, whose I-Thou orientation invites the listener into its posture of transcendental relation.

\section{Being in Darkness}

Although songs that speak in the midst of darkness might not seem relevant to our discussion, sorrow and suffering —as Dante reminds us_can reorient us or open our hearts to God. ${ }^{19}$ To be sure, things aren't always so decisive in popular music; nevertheless, we often find dramatized tales of darkness that involve a religious frame of reference. Typically, post-secular songs of being in darkness signal a distance from their religious allusions and are less than convinced about the possibility of salvation on the other side of their darkness. They thus tend to involve a fugitive or inchoate stirring of religious hope that is suffused with a countervailing sense of despair. (Nick Cave and

\footnotetext{
${ }^{19}$ Dante speaks of a 'good sorrow' that 'remarries us to God' (Purgatorio, XXIII, 81).
} 
Tom Waits frequently sing of or from within this sort of darkness-as did Johnny Cash—though the latter's work is more informed by faith and a more explicitly religious sense of sin.) A particularly affecting 'post-secular' evocation of the self in crisis is to be found in 'The Exchange' by the American singer-songwriter Torres, from her 2015 album Sprinter. What we are presented with in this sparsely accompanied song is the restrained staging of a fall into despair, whose refrain is an enervated distress call that swings between a description of her fall into darkness and an apostrophic call to her parents: 'I'm underwater / Mother, father, I'm underwater'. What carries it into a postsecular territory is its enfeebled and vestigial religious gestures (' $\mathrm{I}$ pray to Jesus Christ incessantly', which runs immediately into 'I shine my shoes for the fat lady' —an allusion to Salinger's Franny and Zooey), which signal a frail and half-forsaken faith, as though the speaker were unpersuaded by her own acts of prayer.

This forlorn stirring of religious hope-that flickers in but can't quite lift itself out of darkness — can of course take a variety of forms. In 'Oh My God, Whatever, Etc', by Ryan Adams, for example, we are confronted with a poignantly aborted prayer that loses conviction almost as soon as it's begun. (In the chorus, the song's trapped and exhausted speaker-perhaps a prostitute, whose gender is unclear-turns briefly away from the bleak surroundings to an outside that seems to offer escape, but which in its temporal concatenations only reinforces the sense of enclosure. And it is, apparently, as this telescoped sense of imprisonment is registered that the speaker's forlorn and foundering prayer flickers into being: 'But the light of the moon leads the way towards the morning and the sun / The sun's well on the way too soon to know and / Oh, oh my God, whatever etc.') On the page, the speaker's 'Oh my God' reads more like an imprecation than an apostrophe-and indeed, in any case, appears to hover inscrutably between a mournful exclamation and a prayerful call. But as it is sung and given space in the song-especially as it is plaintively repeated in the second chorus- the harmonies tilt 
the muted melody into the only minor chord in the song, and the phrase appears disconsolately to lift itself, if not into a fully-fledged I-Thou address then into a momentary reaching out to a beyond that its speaker cannot fully believe in but towards which something inside him or her yearns.

\section{The Interlocuted Listener}

What conclusions can we draw from these examples? Aside from illustrating some of the manifestations of a post-secular stance in popular music, I have in this section attempted to accomplish two principal things: on the one hand, I have sought to show, against Adorno, that popular music does-frequently and in a variety of ways-aspire to engage the imagination of the listener; and on the other hand, adopting an approach that in contrast to Begbie's takes cognizance of music's affects, I have suggested that a divergence from, contestation of, or even perhaps an irreverence towards theological doctrine may paradoxically be of value from a religious point of view. ${ }^{20}$ Central to both of these contentions is the principle of 'transitivity'. ${ }^{21}$ What I wish to designate by means of this phrase is the way popular music invades the listener's space and seeks to draw its auditor into the dramatized events of the song. Of course, one can refuse or fail to

\footnotetext{
${ }^{20}$ Begbie's approach to music assumes that religious significance is solely a matter of doctrinal correspondence, so he interprets any divergence from his Christological template as a defect. (See Begbie (2000: 145-6) and (2007a: 175), in which he criticizes the music of Tavener and Messiaen for its failure to match up with his theological criteria.) He also adopts a curiously 'all or nothing' attitude towards religious content, arguing that only music that evokes all three days of Easter should be endorsed by Christians, and that religious music which doesn't do this should be denounced as pathologically 'sentimental' (2007b: passim). I thus disagree with Begbie on three principal counts: firstly, I want to advocate a wider conception of religious significance that, in addition to matters of 'content', takes cognizance of what music does; secondly, I wish to argue that music that only evokes some aspect of the Christian story may still be of service from a religious point of view (though I would also maintain, against Begbie's one-sided interpretation, that even 'sentimental' music may serve a positive religious function); and thirdly, I want to suggest that artistic divergence on matters of doctrine may have a salutary productive dimension. Indeed, aside from the evangelical advantages of 'weakened' or abbreviated engagements with theological issueswhich may challenge, intrigue or accommodate the message for those outside the church-it seems to me that teasing partial correspondences can be an especially effective way of bringing the particularity of what they fall short of into focus.

${ }^{21}$ The term is borrowed from Shearman, who cites the following gloss of 'transitivity' from the OED as the basis of his definition: 'taking a direct object to complete the sense, passing over to or affecting something else, operating beyond itself (Shearman 1992: 33).
} 
register its 'transitivity' - that is, one can adopt a posture of detached regard. But we do so at a cost, for as D.H. Lawrence reminds us, there are certain religious and poetic experiences that cannot be known 'in apartness' (1928: 331). Thus, whilst it is possible for us to assimilate the world of the song into our time and space, it is equally possible in reverse for the 'interlocuted listener' to accept its offer of imaginative participation and allow the song to involve us in the time and space of its world. So, in 'The Eye Of The Needle', for example, the song's dramatization of a communion celebration locates the listener in the midst of something presently going on, and in doing so relates the questions it poses about belief more immediately to the listener's life. Similarly, in Kendrick Lamar's 'Faith', the song's exploration of the subject in the lives of concretely realized individuals, in the thicket of particular socio-economic circumstances, encourages the imaginative engagement of the listener in a way that propositional instruction might not. Likewise, the epiphanic songs of bands such as Fleet Foxes or Mount Eerie-which draw the engaged listener into a 'shared space' (Shearman 1992: 39)—don't simply narrate sublime encounters for us to marvel at from without, but instead seek to stage an affective analogue of the 'enchanted' experiences they describe. In other words, they aspire to engender an epiphanic experience for the listener. The strategy of 'ludic avowal' can, it seems, also serve as a way of enticing the agnostic or unbelieving listener to inhabit a sceptically inflected space that is at least open to the possibility of faith. And, finally, even the forlorn and subjunctive acts of prayer that fleetingly surface in songs that represent the cries of an apparently isolated self, calling out in anguish-as in 'Oh My God, Whatever, Etc' or 'Into My Arms' - have a potentially 'transitive' dimension too, in that their apostrophic structure draws the engaged listener into their I-Thou orientation and thus invites them to adopt the posture of a believer. (In the conclusion to the next section, I shall reflect upon the importance of such aesthetic 'practices of belief.) In each case, the religious significance of the song is not simply a matter of what it represents, and 
so cannot adequately be evaluated on the basis of 'immanent' models of correspondence. Rather, it is more a matter of what the songs might do-that is, the sorts of experiences they afford, the orientations they foster, the questions they provoke and what they lead the listener towards — or in 'Ricoeurian' terms, the possibilities they open up 'in front of the text. This isn't to say that such weakened or 'post-secular' engagements will in every case have positive effects from a religious perspective. Neither is it proposing to do away with criteria for evaluating what is more or less conducive to the flourishing of faith. But it is to suggest, against Jeremy Begbie, that it may be better to make such evaluations not on the basis of an 'essentialized' system of correspondences between doctrinal criteria and aesthetic forms but rather, in an Augustinian manner, in terms of the music's functions or affects-which is to say, their outworking in the listener's life. It is, we might say, by their fruits that we shall know them.

\section{II \\ THE SWARMING FORMS OF THE BANAL}

In this second section, I want to indicate briefly how the kinds of arguments outlined above may be further extended to apply to non-religious music. In short, I wish to suggest that even 'intrinsically' secular music may be capable of doing religious work. At the centre of this contention is what we might refer to as the epiphanic affordance structures of popular music. ${ }^{22}$ There are of course all sorts of pervasive features of popular music that may help to elicit epiphanic experience-such as its frequently neglected beauty, ${ }^{23}$ its notorious Dionysian force or its ability to stage a moment out of time. ${ }^{24}$ In view of the limitations of space, however, I shall focus on a single and less

\footnotetext{
22 Affordances are the properties of an object or event that suggestively lend themselves to certain actions. ${ }^{23}$ This isn't the place to elaborate a counter-case, but I cannot agree with Martha Bayles, who speaks of a 'loss of beauty' in popular music, which she claims has been replaced by an 'anti-musical' 'ugly excess' (1994: 3-5).

24 See, for example, Frith (1996: chapter 7).
} 
obviously valuable quality — namely, the banality of some of its lyrics. (Having spent the major part of this chapter trying to highlight the abundance of thought, artistry and semiotic complexity that we find in the lyrics of popular music I trust it isn't necessary to belabor the point that this doesn't apply to the whole field-though, as we shall see, it isn't in any case meant pejoratively.)

There are, I think, at least three reasons why one might want to defend the banality of popular music. To begin with, some of its elected banalities may be seen as a version of what Tony Tanner in a discussion of American literature refers to as the adoption of 'a vernacular stance' and 'a calculated act of indecorum', which refuses the genteel hierarchies of admission into the aesthetic sphere and forms part of a larger historical quarrel concerning the constraints of artistic propriety (1996: 84, 67). Secondly, some of the casually redundant and vacuous lyrics in popular music appear to involve a radical devaluation of the semantic function of language-which becomes more of a musical operation or an instrument of sound than a lexical gesture-and which paradoxically aspires to what Michel de Certeau felicitously describes as an opacification of the sign (1992: 144). In fact, some bands—such as Cocteau Twins or Sigur Rós_-even more radically attempt to evade the semantic altogether in their lyrics, by adopting a form of glossolalia, which can convey a sense of going beyond the sayable or of a content that exceeds speech. (Most of us are familiar with the experience of being moved by a song whose lyrics we can't hear or don't understand. This isn't, I suggest, a diminished form of listening experience but rather the condition to which a certain kind of pop music aspires.)

The third reason for defending the banal—which originally meant 'common' or 'open to all'-is the most important for popular music's epiphanic effects. Very briefly, this has to do with the way its lyrics 'afford' or invite the imaginative investment of what Vladimir Konečni calls 'a personal associative context' (2005: passim). What this means is 
that the archetypal or even clichéd nature of many lyrics—-rather like the carefully vague horoscopes one finds in magazines—is part of the songs' affective allure, which invite by virtue of their very banality association with any number of particular contexts. In this sense, like the gaps in literature that elicit the creative involvement of the reader, the broadly drawn and cornily condensed vignettes of popular music solicit the imaginative elaboration of the listener. This 'productive' lack has been neatly characterized by Umberto Eco: 'A text is a lazy mechanism which demands from a reader an extensive co-operation to fill in the blanks of the non-said or of the already-said' (1979: 53). In other words, the notorious banality of popular music-which, as Simon Frith observes, 'represents experience grasped in moments' (1996: 243)—may be seen more positively as a gap-filling affordance structure, whose banality is transmuted in the process of being 'filled out' by the particular associative context of the listener. There is an extraordinary scene in the finale of the second season of the HBO series The Leftovers that vividly illustrates this process of epiphanic appropriation.

Kevin Garvey, a former police chief and principal protagonist, somehow finds himself in a sort of purgatorial realm, where he is told that in order to get back to his family—whom he loves but whom he has betrayed—he must perform a song karaoke on stage. Obviously distressed and incredulous, he eventually makes his way on stage and awkwardly prepares for the unannounced song. (In the background, fanning out either side of his head on the 'wheel of fortune' that determines the choice, one can see Madonna's 'Like A Prayer' and 'Angel Of The Morning' by Juice Newton.) The song he is given is Simon and Garfunkel's 'Homeward Bound', and Garvey-beside himself with terror and grief-gives an excruciatingly stilted performance; until he starts to register what he is singing, that is. For as he absently follows the words of the song, and their relevance to his life starts to dawn on him—awakening memories of his failings and reminding him of those he loves— he becomes more and more emotionally involved in 
the song, which begins to take on a new meaning in front of us. (The advent of Garvey's memories is represented to the viewer by means of fleeting analeptic images from previous episodes - uncannily corresponding to the words of the song-which are extradiegetically woven into the scene.) Indeed, what began as a narrative that seemed to hold no interest to him and had no apparent connection to his life has somehow turned into an expression of his ownmost concerns - a prayer unveiling his deepest longings, a confession of his individual failings-that engenders a moment of anagnorisis, accompanied by 'the gift of tears'. (An allusion to this strangely reflexive processwhereby the singer/listener is reciprocally affected by the song as a result of their emotional investment in it-is cleverly elicited from the line 'All my words come back to me'.) But that is not all. Perhaps the most remarkable thing about this moving scene is that the absurd act of penitential karaoke works. That is to say, after Garvey completes the song and closes his eyes, he suddenly finds himself back with his family in the terrestrial sphere.

In spite of its supernatural setting, this scene illustrates several important things not only about everyday music usage but also about its potential religious significance. Firstly, it offers a dramatic illustration of the peculiar way popular music lends itself to appropriation - in spite of the often considerable distance between the ostensible subject of the lyrics and the listener's associations. Typically, as in Garvey's case, this seems to be made possible by its radically 'underdetermined' character — that is, its tendency to use brief, elliptical and 'banal' phrasings—which opens up its semantic potential. Indeed, what in one sense appears to be a semantic lack is at the same time, paradoxically, the source of its referential superabundance. If this is the case, contrary to Adorno's claims - that the 'standardization' of popular forms fails to engage the imagination-it would seem that the 'banality' of popular music may be a productive feature and an affordance structure, which elicits the listener's emotional investment and imaginative 
participation. (In saying this, I am of course highlighting possibilities—in order to contest Adorno's blanket denunciation—and not talking about what always or necessarily occurs.) There is another, parallel version of this process, which is less witting or less related to popular music's semantic dimension and is more a matter of serendipitous association. For popular music-which invades so many public spaces and often involuntarily accompanies so much of our lives—has a strangely adhesive or absorbent quality, such that it becomes entwined with our otherwise unrelated experiences, whether we wish it or not. Rather like the madeleine in Proust's À la recherche du temps perdu, it then subsequently serves a metonymic repository or aide-mémoire for these experiences, which it can bring flooding back with a piercing epiphanic poignancy. ${ }^{25}$

With this, we have shaded over into the second thing that is illustrated in Garvey's performance of 'Homeward Bound'-namely, popular music's potential to engender transcendence or epiphanic experience. In Garvey's case, the experience involves a dilation of his quotidian vision-in that he is imaginatively transported away from the present and attains a sort of 'posthumous' vision-which elicits a moment of critical awareness about the things he most values in this world. In the phrasing of Charles Taylor, the experience is 'the locus of a manifestation which brings us into the presence of something which is otherwise inaccessible, and which is of the highest moral or spiritual significance' (1989: 419). Whilst Roger Scruton has attempted to persuade us that whereas classical music elicits a quasi-religious posture of contemplation, popular music is incapable of engendering such affects, this sort of epiphanic moment is a commonly reported listening experience. (The most economical way of contesting Scruton's rather imperious attempt to deny an epiphanic potential to popular music is to point towards the wealth of empirical data that testifies to the contrary that many people

\footnotetext{
${ }^{25}$ By sheer coincidence, another Garvey-Guy Garvey, the singer and songwriter of Elbow-has a song ('The Bones Of You'), which describes precisely this experience.
} 
do, in fact, routinely listen to popular music in a contemplative manner and, in the process, experience intimations of transcendence or an epiphanic expansion of vision. ${ }^{26}$ )

The final thing of relevance to our discussion that is illustrated in Garvey's performance is how such epiphanic moments-precipitated by the experience of listening to secular popular music — may be of significance from a religious perspective. Once again, it needs to be emphasized in explaining this that what we dealing with are possibilities and potentialities_openings that we cannot choreograph or secure, but which, pace Scruton, we cannot rule out either; this is because, for some people, such experiences may be devoid of religious significance; whilst for others, although they are believers, these moments may be seen as an 'aesthetic' event and perhaps even a step away from religious engagement. For others, like Garvey in The Leftovers, however, such experiences have a radical transformative potential. (In Garvey's case, the song provokes a moment of illumination, which in turn appears to precipitate an experience of metanoia-since, in accord with the 'confessional' logic of the scene, his penitential karaoke act carries him out of the purgatorial sphere.) This experience of radical transformation might, like Garvey's, be a matter of conscience or a conversion of the heart, which is prompted by a 'kairatic' moment in which one's concerns are re-ordered from a transcendent or epiphanically distended perspective. But this is not the only possibility. The experience of radical transformation may equally be an epistemological matter and pertain to our sense of the possible and real. Prompted by an experience of what Tillich calls 'revelatory ecstasy' (which in his case was elicited by an encounter with a painting in a secular space), it might, in other words, be a moment of unobstructed and dilated vision, in which an ordinarily occluded dimension of reality is fleetingly disclosed-a mysterious 'more' at the heart of being, a haunting, vocative foreign iridescence that pervades and yet exceeds the material order-which Robert Johnston

\footnotetext{
${ }^{26}$ See, for example, Marsh and Roberts (2012: chapter 6).
} 
encourages us to view as an experience of 'general revelation' (2014: chapter 1). And whilst we might emerge the other side of this event without an adequate paraphrase or anything in the world to which we can point, it is an experience that may transfigure our disposition and customary ways of looking at the world. This sort of experience is memorably described by Wordsworth:

\section{the soul,}

Remembering how she felt, but what she felt

Remembering not, retains an obscure sense

Of possible sublimity, whereto

With growing faculties she doth aspire [...]. (The Prelude, II, 334-8)

As C.S. Lewis has argued, with reference to Wordsworth, to 'the perfected Christian' such epiphanic experience may appear to be a dilution of faith or a reprehensible movement from 'Theism to Pantheism'. But to 'the man coming up from below', this sort of 'anonymous' numinous opening may represent 'the first and lowest form of recognition that there is something outside ourselves which demands reverence'. In such circumstances, as Lewis puts it, 'the Wordsworthian experience is an advance. Even if he goes no further he has escaped the worst arrogance of materialism: if he goes on he will be converted' (1940: 22). It seems to me both plausible and important to advocate a parallel argument in relation to popular music. In short, what I am suggesting is that for a contemporary non-believer with no interest in or contact with religious teaching, the epiphanies elicited by popular music may constitute a fecund opening in the desert of materialism that discloses new possibilities for being in the world. And although such experiences, on their own, can perhaps only offer a 'content-less' glimpse of transcendence or a vista onto the infinite mystery of God, they may set us on the path to faith or awaken us to a sense that there is a path; as C.S. Lewis observes-possibly with a nod to Dante, whose pilgrim was of course lured to paradise by a representative of pagan art: 'when we are lost in the woods the sight of a signpost is a great matter' (1955: 238). But perhaps we can venture an even stronger conclusion. 
As Graham Ward has argued in another connection, drawing on the work of Paul Ricoeur, imaginative engagement with secular fiction can be seen as an analogue of religious faith, in that it offers the reader the opportunity to try out new ways of being in the world-which carry us beyond the given-in a 'subjunctive' context of noncommitment (2014: chapter 6). In this sense, I suggest, secular popular music, like secular fiction, offers us 'practices of belief', which for many non-believers (and perhaps some believers!) may be more appealing than more dogmatic programmes of evangelization. What's more, such 'practices' — even though they take place in a fictional sphere-may have real-life, extra-aesthetic affects, since on the one hand they are something in which 'the body collaborates' and which, on account of our psychic investment and somatic involvement, bears 'ontological weight'; but also on the other hand because this sort of practice discloses new ways of being in the world, and in doing so 'forms, reforms and transforms' our 'structures of believing'. In other words, such 'practices' dilate our vision and affect our sense of what is possible and real. As Ward puts it, they are a form of poiesis and not, or not simply, a matter of escapism but rather an expansion of being (2014: $145,155,147)$. To be sure, these imaginative transfigurations are only incipiently, analogically or 'adverbially' religious, and invariably bring with them more questions than answers. They are therefore not a replacement for (though neither are they incompatible with) the 'special revelation' of Scripture. Nevertheless, as religious thinkers such as Coleridge, Newman and C.S. Lewis have argued, on the basis of their own biographical experiences, these transfigurations affected by means of imaginative engagement with secular works of art can constitute a sort of 'praeparatio evangelica' — whose italicized vision opens up and lures us towards new possibilities 'in front of the text—and may thus pave the way for religious belief. As Emily Dickinson expresses it, with characteristic oracular terseness: 'the Possible's slow fuse is lit / By the imagination'. 


\section{BIBLIOGRAPHY}

Bayles, Martha. Hole in Soul: The Loss of Beauty and Meaning in American Popular Culture. Chicago: University of Chicago Press, 1994.

Beaudoin, Tom. Virtual Faith: The Irreverent Spiritual Quest of Generation X. San Francisco: Jossey-Bass Publishers, 1998.

Begbie, Jeremy. Theology, Music and Time. Cambridge: Cambridge University Press, 2000.

Begbie, Jeremy. Resounding Truth: Christian Wisdom in the World of Music. Grand Rapids: Baker Academic, 2007a.

Begbie, Jeremy. The Beauty of God: Theology and the Arts, edited by Daniel Treier, Mark Husbands and Roger Lundin. Illinois: IVP Academic, 2007b.

Berman, Judy. 'Concerning the Spiritual in Indie Rock'. In The Believer, Fall 2015. Available online: http://www.believermag.com/exclusives/?read=article_berman (accessed on 30 April 2016)

Brown, David. God and Grace of Body: Sacrament in Ordinary. Oxford: Oxford University Press, 2007.

Burch Brown, Frank. Good Taste, Bad Taste and Christian Taste: Aesthetics in Religious Life. Oxford: Oxford University Press, 2000.

De Certeau, Michel. The Mystic Fable: Volume One, The Sixteenth and Seventeenth Centuries, translated by Michael B. Smith. Chicago: University of Chicago Press, 1992.

DeNora, Tia. Music in Everyday Life. Cambridge: Cambridge University Press, 2000.

Dyrness, William. Poetic Theology: God and the Poetics of Everyday Life. Grand Rapids: Eerdmans, 2011.

Eco, Umberto. Lector in Fabula. Milan: Bompiani, 1979.

Epstein, Heidi. Melting the Venusberg: A Feminist Theology of Music. New York: Continuum, 2004.

Frith, Simon. Performing Rites: Evaluating Popular Music. New York: Oxford University Press, 1996.

Gabrielsson, Alf. Strong Experiences with Music: Music is much more than just music, translated by Rod Bradbury. Oxford: Oxford University Press, 2011.

Gibson, Owen and Barkham, Patrick. 'A new breed of rock star: quietly Christian'. In The Guardian, 29 January 2005. Available online: http://www.theguardian.com/uk/2005/jan/29/religion.arts (accessed 30 April 2016)

Hopps, Gavin. The Kitsch Epiphany: Popular Music and Radical Wonder (forthcoming).

Johnston, Robert. God's Wider Presence: Reconsidering General Revelation. Grand Rapids: Baker Academic, 2014.

Konečni, Vladimir. 'The Aesthetic Trinity: Awe, Being Moved, Thrills'. In Bulletin of Psychology and the Arts, no. 5 (2005), 27-44.

Krueger, Joel. 'Affordances and the Musically Extended Mind'. In Frontiers in Theoretical and Philosophical Psychology, no. 4 (2013), 1-13.

Lawrence, D.H. A Propos of Lady Chatterley's Lover'. In Lady Chatterley's Lover. 1928. Reprinted, London: Penguin, 2006.

Lewis, C.S. 'Christianity and Culture'. In Christian Reflections. 1940. Reprinted, Grand Rapids: Eerdmans, 1980.

Lewis, C.S. Surprised by Joy. New York: Harcourt, Brace \& World, 1955.

Marion, Jean-Luc. God without Being: Hors Texte, translated by Thomas A. Carlson. Chicago: University of Chicago Press, 1991.

Marsh, Clive and Roberts, Vaughan. Personal Jesus: How Popular Music Shapes Our Souls. Grand Rapids: Baker Academic, 2012. 
McClure, John. Partial Faiths: Postsecular Fiction in the Age of Pynchon and Morrison. Athens, Georgia: Georgia University Press, 2007.

Mertens, Paul. 'Metallica and the God that Failed: An Unfinished Tragedy in Three Acts'. In Call Me Seeker: Listening to Religion in Popular Music, edited by Michael Gilmour. New York: Continuum, 2005.

Partridge, Christopher. The Re-Enchantment of the West, vol. 1: Alternative Spiritualities, Sacralization, Popular Culture, and Occulture. London: T\&T Clark International, 2004.

Ricoeur, Paul. From Text to Action: Essays in Hermenentics, II, translated by Kathleen Blamey and John B. Thompson. 1986. Reprinted, London: Continuum, 2008.

David Sackllah, 'Between Heaven and Hell: The New Wave of Christianity in Indie Rock'. In Consequence of Sound, 29 June 2015. Available online: http:// consequenceofsound.net/2015/06/between-heaven-and-hell-the-newwave-of-christianity-in-indie-rock/(accessed on 30 April 2016)

Small, Christopher. Musicking: The Meanings of Performing and Listening. Hanover, NH: Wesleyan University Press, 1998.

Shearman, John. Only Connect ... Art and the Spectator in the Italian Renaissance. Princeton: Princeton University Press, 1992.

Stevens, Sufjan. Interview in Delusions of Adequacy, 25 September 2006. Available online: http://www.adequacy.net/2006/09/interview-with-sufjan-stevens/ (accessed on 30 April 2016)

Taylor, Charles. Sources of the Self: The Making of the Modern Identity. Cambridge: Cambridge University Press, 1989.

Taylor, Charles. A Secular Age. Cambridge, Mass.: Harvard University Press, 2007.

Viladesau, Richard. Theology and the Arts: Encountering God through Music, Art and Rhetoric. Mahway, New Jersey: Paulist Press, 2000.

Ward, Graham. Unbelievable: Why We Believe and Why We Don't. London: Tauris, 2014.

Wolterstorff, Nicholas. Art in Action: Toward a Christian Aesthetic. Grand Rapids: Eerdmans, 1980.

\section{DISCOGRAPHY}

Ryan Adams, Easy Tiger. Mercury, 2007.

Alabama 3, Exile on Coldharbour Lane. Geffen, 1997.

Lily Allen, It's Not Me, It's You. Parlophone, 2009.

Antony and the Johnsons, Antony and the Johnsons. Durtro, 2000.

Nick Cave, The Boatman's Call. Reprise, 1997.

The Divine Comedy, Regeneration. Parlophone, 2001.

Elbow, The Seldom Seen Kid. Polydor, 2008.

Phil Elverum, Clear Moon. P.W. Elverum \& Sun. 2012; Wind's Poem. P.W. Elverum \& Sun. 2009.

Fleet Foxes, Helplessness Blues. Sub Pop. 2011.

Gowns, Red State. Cardboard, 2007.

Kendrick Lamar, Kendrick Lamar EP. Top Dawg Entertainment, 2009.

Madonna, Like a Prayer. Sire, 1989.

Menahan Street Band, Make the Road by Walking. Daptone, 2008.

Morrissey, You Are the Quarry. Attack, 2004.

Juice Newton, Juice. Capitol, 1981.

Joan Osborne, One of Us. Artemis Strategic, 2005.

Simon and Garfunkel, Parsley, Sage, Rosemary and Thyme. Columbia, 1966.

Torres, Sprinter. Partisan, 2015. 